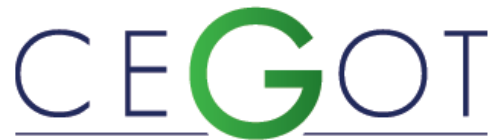

Centro de Estudos de Geografia e Ordenamento do Território
Geografia e Ordenamento do Território, Revista Eletrónica Centro de Estudos de Geografia e Ordenamento do Território http://cegot.org

FERRÃo, ANDRÉ

Universidade Estadual de Campinas. Faculdade de Engenharia Civil, Arquitetura e Urbanismo, Departamento de Recursos

Hídricos Energéticos e Ambientais

6021, Campinas, São Paulo, Brasil, Cidade Universitária "Zeferino Vaz" argollo@fec.unicamp.br

Pozzer, CARLos

Pontifícia Universidade Católica de Minas Gerais, Curso de

Arquitetura e Urbanismo, Departamento de Arquitetura e

Urbanismo

37701-355, Poços de Caldas, Minas Gerais, Brasil, Rua Francis Cletus Cox, Brasil

pozzer@pucpcaldas.br

\title{
O ordenamento territorial no entorno do Lago de Furnas em Minas Gerais: a bacia hidrográfica como unidade de planejamento regional
}

The territorial planning around Furnas Lake in Minas Gerais: the watershed as a regional planning unit

Referência: Ferrão, André; Pozzer, Carlos (2018). O ordenamento territorial no entorno do Lago de Furnas em Minas Gerais: a bacia hidrográfica como unidade de planejamento regional. Revista de Geografia e Ordenamento do Território (GOT), n. ${ }^{\circ}$ 13 (junho). Centro de Estudos de Geografia e Ordenamento do Território, p. 147-176, dx.doi.org/10.17127/got/2018.13.007

\section{RESUMO}

No contexto brasileiro o ordenamento territorial se apresenta como um conceito em processo de construção que ainda não foi devidamente assimilado e experimentado como uma estratégia de planejamento do território nacional. A proposta governamental de implantação de uma Política Nacional de Ordenamento Territorial ainda não se concretizou. Por outro lado, o ordenamento territorial entendido como estratégia de planejamento que extrapola os limites administrativos dos municípios e estados brasileiros pode ser identificado em experiências específicas que se desenvolveram no território nacional nas últimas décadas. $\mathrm{O}$ trabalho desenvolve uma análise sobre as experiências de planejamento no entorno do Lago de Furnas em Minas Gerais reconhecendo-as como estratégias referenciais para o planejamento do território dos pequenos e médios municípios brasileiros.

Palavras-chave: Ordenamento Territorial, Lago de Furnas, Bacia Hidrográfica, Plano Diretor

\section{ABSTRACT}

In the Brazilian context territorial management is presented as a concept in the construction process that has not been properly assimilated and experienced as a country planning strategy. The government proposal for the implementation of a National Territorial Management Policy has not yet materialized. On the other hand, territorial management understood as a planning strategy that goes beyond the administrative limits of the Brazilian cities and its states can be identified in specific experiences that have developed in the national territory in the last decades. The paper develops an analysis of the planning 
experiences in the surroundings of Furnas Lake in Minas Gerais, recognizing them as referential strategies for planning the territory of small and medium Brazilian cities.

Palavras-chave: Territorial Planning, Furnas Lake, Watershed, Master Plan

\section{Introdução}

A assimilação do conceito de Ordenamento Territorial no Brasil foi influenciada por um conjunto de referências legais que de diferentes formas trataram deste tema. A Constituição Federal de 1988, a criação da Política Nacional de Recursos Hídricos de 1997, a promulgação do Estatuto da Cidade em 2001 e os estudos para criação da Política Nacional de Ordenamento Territorial em 2007 podem ser considerados como elementos referenciais para a disseminação do conceito do Ordenamento Territorial no Brasil. Apesar da Política Nacional de Ordenamento Territorial não ter se concretizado, determinadas experiências de nacionais específicas reuniram um conjunto de municípios em torno de determinados objetivos e demandas comuns. Neste contexto, destaca-se as experiências de planejamento das chamadas Unidades de Planejamento e Gestão de Bacias Hidrográficas, definidas a partir de Política Nacional de Recursos Hídricos de 1997, que podem ser consideradas como exemplos referenciais. Nesses processos, muitas vezes, os limites dos territórios municipais foram extrapolados com o objetivo de se planejar, explorar e preservar os recursos hídricos da bacia hidrográfica, que abrigava o território destes mesmos municípios. Para Schiavetti e Camargo (2002) a Bacia Hidrográfica, tornou-se um conceito ampliado que passou a abarcar, nas áreas de planejamento e gestão, os aspectos hidrológicos, a estrutura biofísica, as mudanças nos padrões de uso da terra e os seus efeitos ambientais. No planejamento e na gestão dos recursos hídricos a Bacia Hidrográfica extrapolou os limites políticos legais dos municípios estados e países e passou a ser entendida como uma unidade física de gerenciamento, planejamento e desenvolvimento econômico e social (TUNDISI, 2009; TUCCI, MENDES, 2006). Este trabalho aborda as experiências de planejamento local e regional que se desenvolveram no entorno do Lago de Furnas em Minas Gerais que conferiram a este território um processo de integração regional. Estas experiências são consideradas exemplos referenciais para a adoção de estratégias de Ordenamento 
Territorial, voltadas a um conjunto de municípios brasileiros inseridos numa mesma bacia hidrográfica.

Para o desenvolvimento desta pesquisa foram estudados os já citados marcos legais que consolidaram as reflexões sobre o tema do Ordenamento Territorial no Brasil. Para as análises das experiências de planejamento desenvolvidas no entorno do Lago de Furnas em Minas Gerais, foram estudados: o Plano de Desenvolvimento do Lago de Furnas de 1975, a campanha de elaboração dos Planos Diretores de 2006 e 2007 e o Plano Diretor de Recursos Hídricos da Bacia do Entorno do Reservatório de Furnas (PDRH FURNAS) de 2008. O Plano de Desenvolvimento do Lago de Furnas de 1975, analisado a partir de arquivos eletrônicos fornecidos pela Fundação João Pinheiro de Belo Horizonte, pode ser considerado como principal experiência de ordenamento territorial da região estabelecendo, na época, propostas e diretrizes para o território do entorno do Lago de Furnas. Os documentos referentes à campanha dos Planos Diretores e do PDRH FURNAS foram disponibilizados pela Associação dos Municípios do Lago de Furnas (ALAGO).

O artigo organiza-se com uma reflexão inicial sobre o conceito de Ordenamento Territorial no Brasil e com uma análise das referidas experiências de planejamento no entorno do Lago de Furnas.

\subsection{A Evolução do enquadramento legal do Ordenamento Territorial no Brasil}

As primeiras referências sobre o conceito do Ordenamento Territorial no Brasil surgiram no contexto da Assembleia Nacional Constituinte de 1988 com a influência dos debates que ocorriam na Europa no processo de implantação da União Europeia.

Nesse período consolidou-se na Europa um discurso institucional sobre o caráter transnacional do espaço europeu. Até então o conceito de território estava ligado às ideias de cidadania e soberania nacional e as políticas de ordenamento territorial tinham uma abrangência nacional. Já a estratégia da União Europeia exigia uma visão do conjunto do território europeu com o objetivo de combater as disparidades regionais e promover a sua integração (FERRÃO, 2010). 
A Carta Europeia do Ordenamento do Território, aprovada em 1984 pelo Conselho da Europa, apresentava os princípios e objetivos assumidos pelos seus membros para o almejado ordenamento transnacional do espaço europeu. O Ordenamento Territorial era visto como um importante instrumento da sociedade europeia que transcendia os conceitos de desenvolvimento nacional, regional e local promovendo uma cooperação que visava a redução das disparidades regionais, a melhoria do uso e organização do espaço, a proteção do meio ambiente e a melhoria da qualidade de vida. O Ordenamento do Território deveria ser desenvolvido dentro de uma perspectiva interdisciplinar e integrada, visando o desenvolvimento equilibrado das regiões e a organização física do espaço segundo uma estratégia de conjunto. A melhoria da qualidade de vida das populações em ambientes planejados e equilibrados seria o objetivo prioritário do Ordenamento Territorial (Conselho da Europa, 1988).

A Constituição Federal do Brasil de 1988, em seu Art. 18, considerou o município como uma entidade autônoma da organização político-administrativa do país. Os municípios brasileiros assumiram então a competência de legislar sobre assuntos de interesse local, promover o adequado ordenamento territorial através do planejamento e controle do uso, do parcelamento e da ocupação do solo urbano. O Capítulo II da Política Urbana da Constituição Federal, nos artigos 182 e 183, estabeleceu que a política de desenvolvimento urbano executada pelo Poder Público do Município deveria ter como objetivo o pleno desenvolvimento das funções sociais da cidade e a garantia do bem-estar dos seus habitantes. O Plano Diretor era apresentado então com um documento político que deveria ser aprovado pela Câmara Municipal, sendo obrigatório para as cidades com mais de 20.000 habitantes, identificando-se como o instrumento básico da política de desenvolvimento e expansão urbana municipal. A propriedade urbana cumpriria a sua função social quando atendesse as exigências fundamentais de ordenação da cidade expressas no Plano Diretor (BRASIL, 1988).

O capítulo VI da Constituição Federal assegurava que toda a população teria direito ao meio ambiente ecologicamente equilibrado, cabendo ao Poder Público e à coletividade o dever de defendê-lo e preservá-lo. Todos as unidades da Federação, ou seja, a União, os estados e os municípios deveriam definir espaços territoriais e seus componentes a serem 
especialmente protegidos vedando qualquer utilização que comprometam a integridade dos seus atributos ambientais (BRASIL, 1988).

Cabe ressaltar que o Plano Diretor previsto na Constituição Federal se restringia aos limites dos municípios com mais de 20.000 habitantes, não estabelecendo referências às regiões nas quais estes mesmos municípios estariam implantados. A questão regional seria tratada no artigo 21 da Carta Magna, atribuindo à União o encargo da elaboração e execução de planos nacionais e regionais de ordenação do território e de desenvolvimento econômico e social.

A Constituição Federal no parágrafo $3^{\circ}$ artigo 25 estabelecia que os Estados brasileiros poderiam, mediante lei complementar, instituir regiões metropolitanas, aglomerações urbanas e microrregiões, constituídas por agrupamentos de municípios limítrofes, para integrar a organização, o planejamento e a execução de funções públicas de interesse comum (BRASIL, 1988). As aglomerações urbanas designavam espaços urbanos situados em nível sub-metropolitano que agregariam mais de uma cidade que teriam ou estariam experimentando processos de conurbação (MATOS, 2000). Já as microrregiões brasileiras que seriam uma possível alternativa para a atuação cooperativa e integrada dos municípios brasileiros limítrofes não foram devidamente implementadas servindo mais como um recurso para as pesquisas estatísticas e menos para o desenvolvimento de estratégias de planejamento e gestão do território.

Mais tarde, com a Lei no 10.683 de 28 de maio de 2003, que tratava da organização da Presidência da República e dos Ministérios, a ordenação do território passou a ser entendida como uma política de Estado sendo delegada aos ministérios de Integração Nacional e da Defesa, abrangendo ainda ações e iniciativas de outros ministérios como Meio Ambiente, Cidades e Desenvolvimento Agrário (BRASIL, 2003). Entretanto em 2017, no conturbado momento político vivido pelo país, a referida lei foi revogada pela Medida Provisória 782 e a ordenação do território passou a se configurar apenas como responsabilidade do Ministério da Integração Nacional (BRASIL, 2017).

A Constituição Federal do Brasil de 1988 dividiu a organização política-administrativa do País nas seguintes entidades federativas: União, Estados, Distrito Federal e Municípios. Na definição das competências em matéria de ordenamento territorial estabeleceu-se como 
responsabilidade da União: a elaboração de planos nacionais e regionais de ordenação do território e desenvolvimento econômico e social; o planejamento e a promoção da defesa contra calamidades públicas, secas e inundações, a instituição do sistema nacional de gerenciamento de recursos hídricos e a instituição de diretrizes para o desenvolvimento urbano, habitação saneamento básico e transportes urbanos. Os Estados, regidos por suas respectivas Constituições Estaduais, assumiram a responsabilidade da criação das já citadas regiões metropolitanas, aglomerações urbanas e microrregiões para o desenvolvimento de ações de planejamento regional. Por outro lado, os Municípios regidos por suas respectivas Leis Orgânicas, assumiram a competência de planejar e ordenar o território municipal (BRASIL, 1988). Nessa proposta de organização política-administrativa do País, a competência do planejamento do território regional foi atribuindo primeiramente à União, podendo os Estados com a criação das regiões metropolitanas, aglomerações urbanas e microrregiões contribuir com este processo. Apesar dos municípios brasileiros terem autonomia para planejarem o seu território municipal existe, contudo, a carência do estabelecimento de estruturas ou experiências organizacionais efetivas que permitam o planejamento e a integrado do território regional.

\section{O Planejamento das Cidades no Brasil}

A Constituição Federal de 1988 consagrou o Plano Diretor como instrumento básico da política de desenvolvimento e expansão urbana no Brasil, sendo a sua elaboração da responsabilidade dos municípios. A Carta Magna reconheceu então a importância desse instrumento urbanístico para a organização e gestão das cidades brasileiras, obrigando ainda que cidades com mais de 20.000 habitantes elaborassem seus próprios Planos Diretores.

A referida política de desenvolvimento e expansão urbana deveria ordenar o pleno desenvolvimento das funções sociais da cidade e garantir o bem-estar dos seus habitantes. O Plano Diretor deveria estabelecer as exigências fundamentais para ordenação da cidade que regulamentariam o cumprimento da função social da propriedade urbana. 
A Carta Magna brasileira apontava então para a necessidade de elaboração de um novo modelo de Plano Diretor, muito diferente da maioria dos planos que haviam sido experimentados no contexto nacional. Em 1964, no início do Governo da Ditadura Militar no Brasil, foi criado Serviço Federal de Habitação e Urbanismo (SERFHAU) que além das questões habitacionais passou a desenvolver ações específicas de planejamento urbano abrangendo processos relacionados à elaboração de Planos Diretores (MOTA, 2007). O SERFHAU passou então a induzir os municípios brasileiros a elaborarem seus Planos Diretores. A realização do Plano Diretor passou a se constituir um requisito para investimentos públicos governamentais. Muitas cidades tiveram que gastar vultosos recursos financeiros na contratação de Planos Diretores para obtenção de financiamentos das obras de infraestruturas municipais. Entretanto os altos investimentos dispendidos na contratação desses planos junto ao SERFHAU demonstraram-se como inócuos uma vez que a maioria desses planos foi arquivada ou esquecida pelos gestores municipais (BOLAFFI, 1982; FERREIRA, 2007).

Diferentemente dos planos do SERFHAU, o novo modelo de Plano Diretor estabelecido pela Constituição Federal de 1988, devia explicitar as exigências fundamentais de ordenação da cidade para que a propriedade urbana cumprisse a sua função social (BRASIL, 1988).

Para viabilização da aplicação do Capítulo da Política Urbana da Constituição Federal foi necessária sua regulamentação através da Lei $\mathrm{n}^{\circ} 10.257$ de 10 de julho de 2001, denominada Estatuto da Cidade. A referida lei estabelecia que política urbana deveria objetivar a ordenação do pleno desenvolvimento das funções sociais da cidade e da propriedade urbana em prol do bem coletivo, da segurança do bem-estar dos cidadãos e do equilíbrio ambiental (KRINGS; ROSSIN; PHILIPPI JUNIOR, 2006).

A ordenação das funções sociais da cidade e da propriedade urbana garantiria assim o direito às cidades sustentáveis que viabilizariam: o direito à terra urbana, à moradia, ao saneamento ambiental, à infraestrutura urbana, ao transporte, ao lazer, aos serviços públicos e ao trabalho para as presentes e futuras gerações.

$\mathrm{Na}$ política urbana municipal o planejamento do desenvolvimento das cidades e do território sobre sua influência deveria evitar e corrigir distorções no crescimento urbano e seus efeitos negativos sobre o meio ambiente. Nesse sentido a adoção de padrões de 
produção e consumo de bens e serviços de expansão urbana deveriam ser compatíveis com os limites da sustentabilidade ambiental, social e econômica do município e do território sobre sua área de influência.

O Estatuto da Cidade estabelecia no seu Capítulo III que a propriedade urbana cumpriria a sua função social quando atendesse às exigências fundamentais de ordenação da cidade expressas no Plano Diretor. O Plano Diretor, que devia ser aprovado por uma lei municipal, deveria englobar o território do município como um todo, ou seja, abrangendo tanto a área urbana como a área rural, constituindo-se como instrumento básico da política de desenvolvimento e expansão urbana do município (BRASIL, 2001).

O artigo 39 do Estatuto da Cidade, estabeleceu que a Lei que instituísse o Plano Diretor devia ser revista pelo menos a cada dez anos. O processo de elaboração do Plano Diretor e a fiscalização de sua implantação devia compreender um processo participativo que garantisse o desenvolvimento de audiências públicas e debates, a publicidade e o acesso aos documentos e informações produzidas (BRASIL, 1988; BRASIL; 2001). Consolidava-se assim um novo modelo de Plano Diretor que não devia ser feito apenas por técnicos contratados ou pelas equipes técnicas das prefeituras municipais, devia agora envolver a comunidade e as entidades locais no processo de elaboração dos Planos Diretores que passaram a ser nomeados como Planos Diretores Participativos.

Entretanto, o Estatuto da Cidade deixou de abordar em seu texto as questões regionais que extrapolam os limites político-administrativos dos municípios e que estabelecem consideráveis influências e impactos nos processos de urbanização das cidades brasileiras. Nesse contexto as diretrizes de desenvolvimento e expansão territorial do município bem como as suas conceituações para a Função Social da Propriedade e da Cidade não se articularam necessariamente com um projeto de desenvolvimento do território regional (BRASIL, 2004).

\section{O Planejamento das bacias hidrográficas no Brasil}

Além das aglomerações urbanas, previstas na Constituição Federal e regularmente estabelecidas, existem no Brasil outros tipos de agrupamentos de municípios que se 
estruturaram a partir de identidades históricas microrregionais, processos produtivos, redes educacionais, programas institucionais e acordos relacionados ao uso e a exploração dos recursos naturais. Destaca-se nesse último aspecto a experiência acumulada nos processos de planejamento e gestão das Bacias Hidrográficas Brasileiras que integraram os municípios nos processos de planejamento e gestão das águas regionais (BRASIL, 2004).

Em 1997 foi promulgada a Lei Federal no 9433 que instituiu a Política Nacional de Recursos Hídricos (PNRH) definindo a bacia hidrográfica como base territorial de planejamento e gestão da água. Estabelecia-se então que a gestão dos recursos hídricos deveria ser descentralizada garantindo a participação do Poder Público dos usuários e da comunidade. A PNRH tinha como um dos seus objetivos a utilização racional e integrada dos recursos hídricos. As suas diretrizes estabeleciam uma gestão sistemática dos recursos hídricos que deveria ser adequada às diversidades ambientais, socioeconômicas e culturais das diversas regiões brasileiras. A gestão dos recursos hídricos deveria ser integrada à gestão ambiental. O planejamento dos recursos hídricos deveria articular-se com os setores dos usuários e com as estratégias de planejamento regional, estadual e nacional (BRASIL, 1997).

A PNRH estabelecia ainda os seguintes instrumentos de planejamento e gestão dos recursos hídricos: Planos de Recursos Hídricos; o enquadramento dos corpos d'água; a outorga dos direitos de uso; a cobrança pelo uso; a compensação aos municípios e o Sistema de Informações sobre os Recursos Hídricos. Os Planos de Recursos Hídricos eram então definidos como planos diretores que fundamentariam e orientariam a implementação da PNRH (BRASIL, 1997).

A Lei no 9433/97 apresentava então uma nova modalidade de Plano Diretor, ou seja, o Plano de Recursos Hídricos que compreenderia um conjunto de ações, diretrizes e propostas de longo prazo para a Bacia Hidrográfica. Os Planos de Recursos Hídricos das Bacias Hidrográficas brasileiras orientariam a implantação da PNRH. Os objetivos e diretrizes da Lei no 9433/97 abarcavam então o planejamento e a gestão dos recursos hídricos inseridos dentro dos territórios municipais exigindo a integração e articulação com a gestão ambiental e o uso do solo.

Nesse sentido o planejamento do uso do solo dos municípios que até então eram temas específicos dos Planos Diretores e das Leis Municipais de Zoneamento e de Uso e Ocupação 
do Solo passaram também a ser objeto dos Planos de Recursos Hídricos. As bacias hidrográficas e os Planos de Recursos Hídricos abrangem territórios que extrapolam os limites municipais, integrando na maioria das vezes vários municípios. Muitos desses municípios teriam mais de 20.000 habitantes e conforme o disposto no capítulo da Política Urbana da Constituição Federal, deveriam elaborar, ou, já teriam elaborado seus Planos Diretores. Nesse contexto, a política de desenvolvimento e expansão urbana que deveria ser expressa nos Planos Diretores visando o cumprimento das funções sociais da propriedade urbana e da cidade, deveriam contemplar também as diretrizes e propostas previstas nos Planos de Recursos Hídricos. Da mesma forma, os Planos de Recursos Hídricos deveriam observar as diretrizes e propostas dos Planos Diretores Municipais.

As Agências de Águas, entidades criadas pela Lei no 9433/97 para dar suporte técnico aos Comitês de Bacia Hidrográfica, são responsáveis pelo processo de elaboração do Plano de Recursos Hídricos. Já o Comitê de Bacia Hidrográfica, composto por representantes da União, dos Estados, dos Municípios, dos usuários das águas e das entidades civis de recursos hídricos com atuação na bacia hidrográfica, tem a responsabilidade de aprovar o Plano de Recursos Hídricos e acompanhar o seu processo de implantação (BRASIL, 1997).

Cabe ressaltar que o Plano de Recursos Hídricos deve necessariamente abordar, entre outros aspectos, questões relativas aos padrões de uso e ocupação do solo na Bacia Hidrográfica. Entretanto, a vinculação das diretrizes Plano Diretor de Recursos Hídricos com o Plano Diretor Municipal ainda não se configura como uma obrigatoriedade legal. Porém, em 2012, devido ao expressivo aumento dos desastres ambientais no território brasileiro, em especial o ocorrido em 2011 na chamada região serrana do Rio de Janeiro, quando mais de 900 pessoas perderam as suas vidas, influenciou a promulgação da Lei no 12.608 de 10 de abril de 2012 que instituiu a Política Nacional de Proteção e Defesa Civil. Na referida lei, os municípios inseridos no Cadastro Nacional de Municípios suscetíveis à ocorrência de deslizamentos de grande impacto, inundações bruscas ou processos geológicos ou hidrológicos correlatos tinham que obrigatoriamente integrar as diretrizes do Plano Diretor Municipal com o conteúdo do Plano Diretor de Recursos Hídricos. O referido cadastro nacional de municípios suscetíveis a desastres ambientais, infelizmente, ainda não foi elaborado, entretanto a exigência da integração do planejamento das águas com o 
planejamento do território deveria obrigatoriamente ser observada por todos os municípios brasileiros (BRASIL, 1997; BRASIL, 2012; BUSCH; AMORIM, 2011).

O Plano Diretor de Recursos Hídricos, com o seu enfoque regional e participativo, apresenta-se, desde a promulgação da Política Nacional de Recursos Hídricos de 1997, como um dos principais instrumentos brasileiros de ordenamento territorial que extrapola os limites político-administrativos dos municípios objetivando, entre outros temas, a utilização racional e integrada das águas com vistas ao desenvolvimento sustentável.

\section{A Política Nacional de Ordenamento Territorial: situação atual}

No contexto brasileiro a assimilação do Ordenamento Territorial como um instrumento de planejamento governamental ainda se configura como um processo inacabado. 0 reconhecimento governamental sobre a relevância do tema nos primeiros anos do século XXI induziu o desenvolvimento de uma série de eventos, seminários e a produção de documentos oficiais que promoveram uma abordagem reflexiva sobre a possível implantação da Política Nacional de Ordenamento Territorial no Brasil (PNOT). Entretanto, a não regulamentação dessa referida política, enfraqueceu o debate sobre o tema e as possíveis experiências de planejamento no campo do Ordenamento Territorial e foram substituídas por um conjunto de ações estratégicas nomeadas como de desenvolvimento regional objetivando o enfrentamento dos chamados "desequilíbrios regionais brasileiros".

Na PNOT o ordenamento do território deveria ser entendido como um processo no qual seriam obrigatórios o conhecimento e a consideração dos interesses e demandas públicas e privadas para definição dos usos possíveis e aceitáveis no território nacional. Além dos critérios técnicos, ambientais, territoriais e socioeconômicos o ordenamento deveria necessariamente objetivar o desenvolvimento econômico, a qualidade de vida e a preservação do meio ambiente (SANTOS, 2005). 


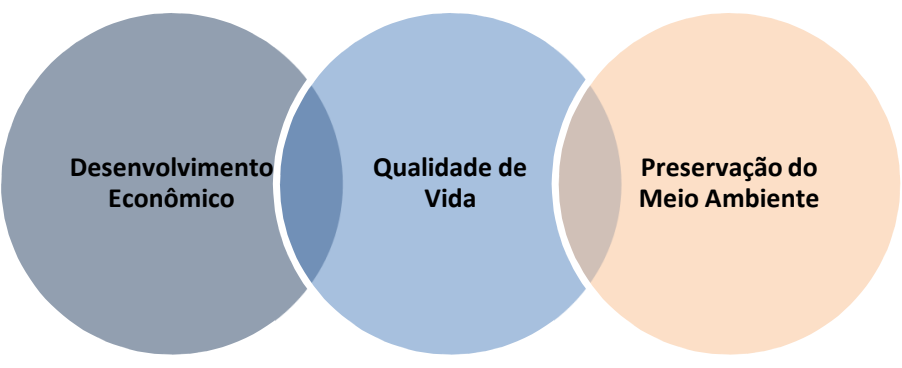

Figura 1 - Principais Critérios da PNOT

Fonte: SANTOS, 2005.

A hierarquização desses critérios tomaria como referência um modelo territorial futuro, um cenário desejável de país que se pretenderia atingir através do ordenamento. Seriam então ordenados os múltiplos usos do território e de seus recursos naturais. Os propósitos do ordenamento territorial abrangeriam: o desenvolvimento socioeconômico equilibrado das regiões, a melhoria da qualidade de vida, a gestão responsável dos recursos naturais, a utilização racional do território. Nesse contexto o mercado não poderia mais ser entendido como o único determinante do ordenamento territorial. A concentração econômica muitas vezes promovida pelo mercado seria entendida como um fator gerador das desigualdades regionais. Caberia então ao Estado, a elaboração de planos nacionais e regionais de ordenação do território e de desenvolvimento econômico e social (SANTOS, 2005).

Em fevereiro de 2007 foi publicado o Decreto no 6047 que instituiu a Política Nacional de Desenvolvimento Regional (PNDR). $O$ decreto mencionava 0 enfrentamento das desigualdades de nível de vida entre as regiões brasileiras, a promoção da equidade no acesso a oportunidades de desenvolvimento, além da orientação dos programas federais no território nacional. A PNDR teria como estratégias: o estímulo ao desenvolvimento regional e a articulação das ações públicas, e investimentos nos territórios selecionados. Essas estratégias teriam ainda que convergir-se com os objetivos de inclusão social, produtividade, sustentabilidade ambiental e competitividade econômica (BRASIL, 2007).

Em julho de 2007 foi instituído o Grupo de Trabalho Interministerial (GTI) com a finalidade de elaborar a proposta da PNOT, contando com representantes da Casa Civil, Ministério da Integração Nacional, Ministério da Defesa, Ministério do Planejamento, Orçamento e Gestão, Ministério do Meio Ambiente, Ministério das Cidades, Ministério do Desenvolvimento Agrário e Ministério de Minas e Energia (BRASIL, 2007). 
Em dezembro de 2007 o GTI concluiu a elaboração da minuta do Projeto de Lei que instituía a PNOT encaminhando o documento para a Casa Civil da Presidência da República, para apreciação e posterior envio ao Congresso Nacional (MIRAGAYA; SIGNORI, 2011). Passados quase dez anos da conclusão deste processo a PNOT ainda não foi implantada.

A PNOT estabeleceu uma reflexão sobre uma estratégia de planejamento que extrapolaria as fronteiras político-administrativas dos municípios e estados brasileiros, enfocando o desenvolvimento econômico, a qualidade de vida e a preservação do meio ambiente. Apesar do ordenamento territorial não ter se efetivado enquanto uma política oficial governamental, determinadas experiências distribuídas no território nacional procuraram romper o isolamento dos municípios promovendo processos integrados em busca de objetivos comuns de um conjunto de cidades.

Nas campanhas desenvolvidas pelo Ministério das Cidades, desde 2003, nos processos de sensibilização e capacitação para elaboração dos Planos Diretores destaca-se duas experiências que abordaram o território de um conjunto integrado de municípios ao invés do planejamento isolado de cada cidade. O Estatuto da Cidade exigia que os municípios inseridos na área de influência de empreendimentos ou atividades de significativo impacto ambiental regional ou nacional elaborassem os seus Planos Diretores, mesmo que estes municípios tivessem população menor que 20.000 habitantes. Sendo que, os recursos técnicos e financeiros necessários à elaboração dos planos, seriam inseridos nas medidas compensatórias que deveriam ser adotadas. Nesse contexto os municípios do entorno do Lago da Hidrelétrica de Tucuruí, no estado do Pará, e os municípios do entorno do Lago de Furnas, em Minas Gerais, foram obrigados a elaborar seus Planos Diretores até o final de 2006 quando esgotava o prazo legal estabelecido pelo Estatuto da Cidade. Para assessoria à elaboração dos Planos Diretores o Governo Federal e o Ministério das Cidades instituíram convênios de cooperação técnica em parceria com as entidades públicas, institucionais e a sociedade civil destas regiões para o desenvolvimento dos referidos planos (BRASIL, 2005).

No Pará o processo de planejamento envolveu os sete municípios do entorno do Lago de Tucuruí; já a campanha dos Planos Diretores do entorno do Lago de Furnas envolveu 50 municípios representando a experiência mais abrangente de planejamento local e regional desenvolvida no país. Mais do que responder as demandas legais relacionadas aos prazos de elaboração dos planos as experiências estabeleceram uma reflexão sobre a necessidade do 
planejamento integrado do território de um conjunto de municípios em contraposição à tradição do planejamento isolado do território municipal. Os impactos causados pelo processo de implantação das referidas usinas hidrelétricas tiveram uma abrangência regional, neste contexto o simples cumprimento do texto legal do Estatuto da Cidade, ou seja, a elaboração do Plano Diretor de cada município afetado, deve ser entendido como uma primeira etapa dos processos de planejamento voltados prioritariamente para a escala local. Uma segunda, e fundamental contribuição deste processo seria a elaboração de um plano regional que integrasse o conjunto dos municípios envolvidos para o enfrentamento de temas e demandas territoriais comuns. Entretanto, no contexto brasileiro, não existe uma exigência legal, para elaboração destes referidos planos regionais. Neste contexto, o Plano de Desenvolvimento do Lago de Furnas de 1975, elaborado com o objetivo de atenuar os impactos causados na região, pelo processo de implantação da usina hidrelétrica e pelo Lago de Furnas, pode ser considerado como uma importante experiência brasileira voltada ao planejamento do território regional.

\section{O ordenamento territorial no Entono do Lago de Furnas.}

\subsection{O Plano de Desenvolvimento do Lago de Furnas (PDLF)}

O Lago e a Usina de Furnas foram implantados no sudoeste de Minas Gerais, no período de 1956 a 1965, atendendo ao projeto desenvolvimentista do Plano de Metas do Governo Juscelino Kubitschek. A Usina de Furnas foi construída com o objetivo de atender parte do conteúdo da Meta de Energia garantindo o fornecimento de eletricidade para os estados de São Paulo, Rio de Janeiro e Minas Gerais (BRASIL, 1958; CONTRIM 1994).

A barragem construída no encontro do Rio Grande com o Rio Sapucaí, na região conhecida como Corredeiras de Furnas, possibilitou a execução da primeira usina hidrelétrica brasileira de grande porte que viabilizou o desenvolvimento de parte da Região Sudeste do Brasil, mas que ao mesmo tempo provocou graves impactos socioeconômicos nos municípios atingidos.

O Lago de Furnas com os seus dois braços do Rio Grande e do Rio Sapucaí, inundaram aproximadamente $1400 \mathrm{~km}^{2}$ de terras, atingindo 32 municípios, provocando cerca de 8.000 
desapropriações que atingiram desde pequenas casas até grandes fazendas. Muitas pessoas perderam seus bens e suas condições de subsistência na região (LEMOS JÚNIOR, 2010).

Entretanto, o Lago de Furnas passou a interligar um conjunto de municípios, dos quais muitos deles, até então, não desenvolviam significativas relações socioeconômicas e culturais conformando então uma nova região formada inicialmente por 32 municípios do seu entorno.

Em 1975, para o enfrentamento dos graves impactos socioeconômicos causados pelo Lago de Furnas, o Governo de Minas Gerias e FURNAS contrataram A. J. Gray, ex-chefe da Equipe de Planejamento Regional da Tennessee Valley Authority (TVA), para a coordenação do Plano de Desenvolvimento do Lago de Furnas (MINAS GERAIS, 1975).

A TVA foi uma das agências de desenvolvimento criadas pelo Governo Roosevelt nos Estados Unidas em 1933 para enfrentar a chamada Grande Depressão vivida pelo país naquele período. A TVA ganhou notoriedade internacional ao aliar a exploração dos recursos ambientais do Vale do Tennessee com a melhoria das condições de vida da população local. O sucesso das experiências da TVA levou a empresa a prestar consultorias internacionais no campo da produção de energia hidrelétrica e em experiências de planejamento regional (HALL, 2005).

O Plano de Desenvolvimento do Lago de Furnas (PDLF) foi estruturado a partir de três objetivos iniciais, ou seja: estabelecer uma linha de ação para o desenvolvimento da região envoltória ao lago; escolher a área prioritária para desenvolvimento e definir indicações para implantação de um sistema gestor para a execução do plano. 


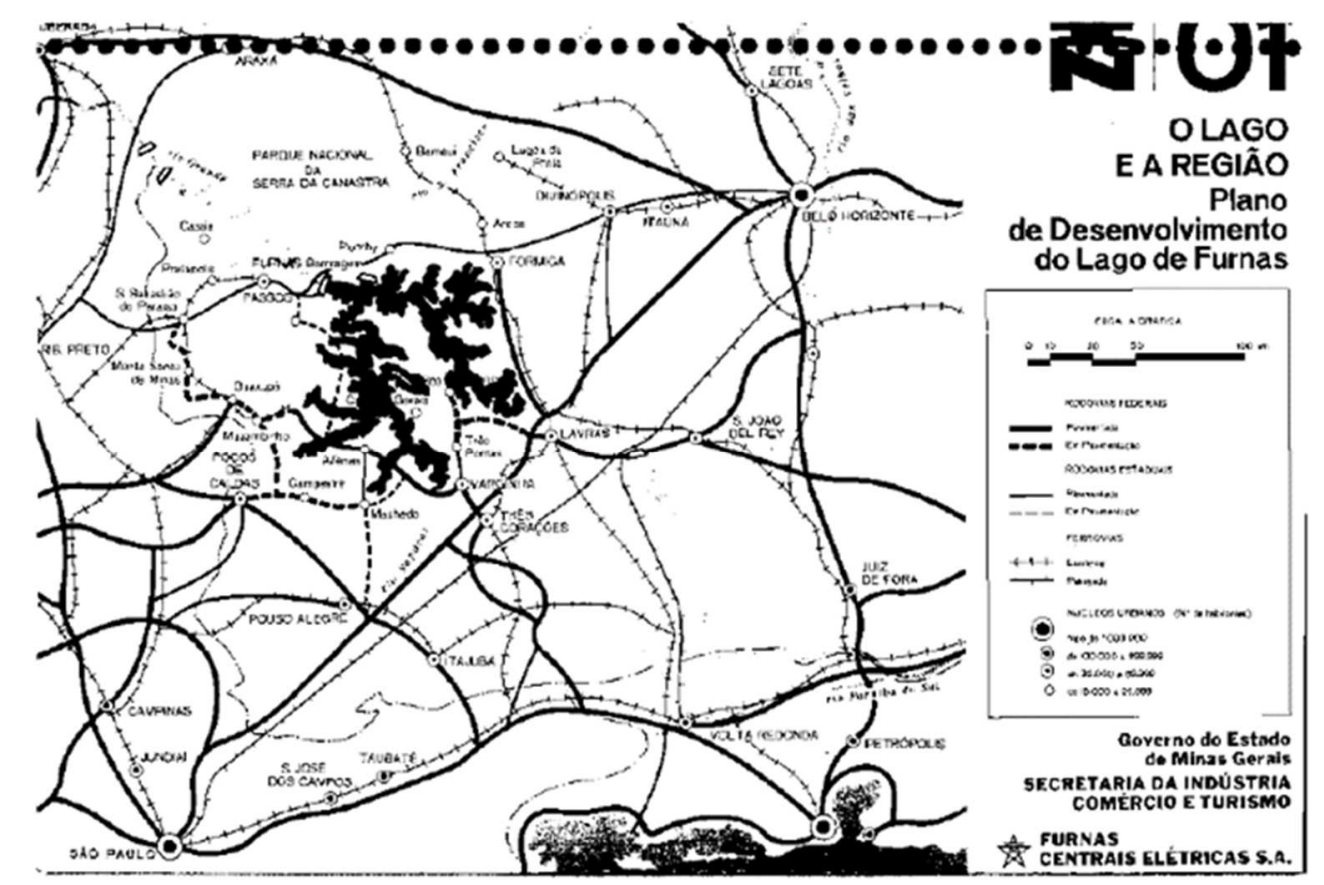

Figura 2 - Mapa da Região do Lago de Furnas Fonte: MINAS GERAIS, 1975.

O PDLF considerou o Lago de Furnas como importante equipamento turístico a ser usufruído pela população da região sudeste do Brasil, que na época abrigava aproximadamente $40 \%$ da população nacional. Os autores do plano indicavam a implantação de atividades recreativas e turísticas junto às margens do Lago de Furnas.

O diagnóstico do plano identificava, na época, o predomínio de pequenas propriedades agrícolas no entorno do Lago, e previa que com os avanços tecnológicos haveria uma fusão das terras com o surgimento de propriedades maiores que provocariam a diminuição da oferta do emprego rural. Para evitar a migração dos moradores da região rumo às grandes cidades brasileiras, o PDLF apontava a necessidade da criação de novos postos de trabalho na região. O plano teria uma duração de 20 anos, com revisões a cada cinco anos, pretendendo nas suas propostas de desenvolvimento aumentar a renda da população rural, controlar a erosão e industrializar as pequenas cidades da região.

O programa de desenvolvimento compreendia o aprimoramento da infraestrutura dos núcleos urbanos com a implantação de distritos industriais planejados, programas habitacionais de qualidade e capacitação da mão de obra local para o trabalho nas futuras indústrias que deveriam ser implantadas na região. 
O plano previa ações voltadas à melhoria das técnicas agrícolas utilizadas; aumento da produção e renda rural; reflorestamento e controle da erosão das terras do entorno do Lago de Furnas. Ao aprimorar as técnicas agrícolas na região, o plano pretendia evitar os efeitos da erosão do solo bem como a condução de fertilizantes para dentro do Lago de Furnas. $O$ descontrole de processo poderia provocar o crescimento excessivo da vegetação aquática prejudicando os pretendidos usos recreativos e de pesca no lago. Programas de reflorestamento seriam implantados em toda a extensão do lago objetivando a redução do assoreamento e a turvação do mesmo. A piscicultura comercial foi indicada como uma atividade econômica possível de ser implantada em determinadas regiões do Lago de Furnas.

A inexistência de um sistema regional de rodovias pavimentadas interligadas aos grandes centros populacionais da Região Sudeste era identificada como um dos principais entraves para o desenvolvimento turístico da região.

O Plano apontava para as características das águas do sul do Lago de Furnas, que nos períodos de chuvas tornavam-se turvas e sem atrativos para o turismo. Já a metade norte do lago, onde a água seria cristalina o ano todo, foi indicada como a região mais adequada às atividades recreativas e turísticas (Figura 3).

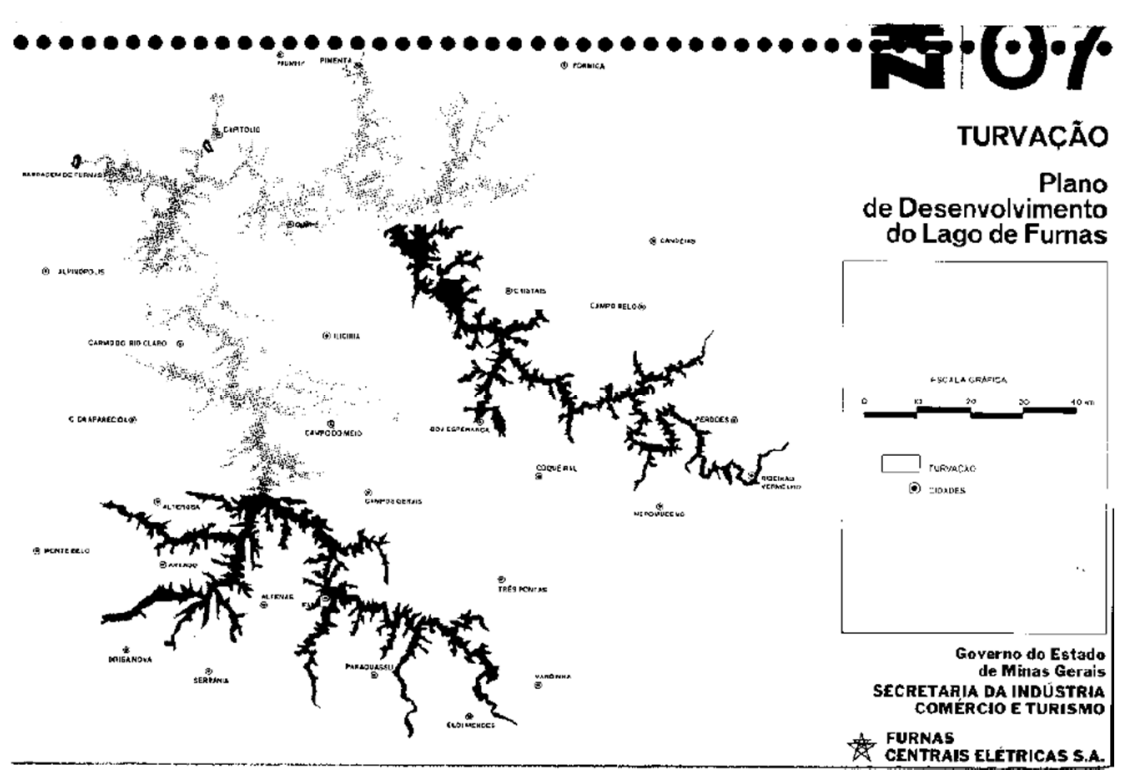

Figura 3 - Mapa de Turvação do Lago de Furnas Fonte: MINAS GERAIS, 1975.

O PDLF identificou diferentes atributos para terras situadas ao norte e ao sul do Lago de Furnas. Na região norte existiam terrenos inclinados, montanhas, altos platôs, escarpas 
íngremes e cânions que poderiam ser explorados com atividades turísticas. Já a região sul era caracterizada por colinas suavemente onduladas, com pouca variedade morfológica possuindo solos indicados para usos agrícolas.

Destacavam-se as características geológicas da região norte, a montante da barragem, onde o lago se aprofundava em vários cânions, que podiam ser observados através de incursões com barcos. Estes cânions tinham relevantes características cênicas, que podiam ainda ser observados através de mirantes que existiam no topo das escarpas. O PDLF, destacando os atributos paisagísticos desta região, indicava a adoção de ações específicas para a exploração das qualidades deste território.

De certa maneira o PDLF apresentou uma proposta de zoneamento para o território no entorno do Lago de Furnas indicando usos agrícolas para a região sul e a implantação de florestas, pastagens e um conjunto de atividades turísticas para a região norte. O plano reconhecia que as atividades turísticas não poderiam se sobrepor ao objetivo básico da execução do Lago de Furnas, ou seja, a produção de energia elétrica.

A pesca turística foi indicada como a principal atração do lago. Sugeria-se o desenvolvimento de um conjunto de eventos que deveriam ser programados para divulgação dos recursos turísticos do Lago de Furnas, como competições estaduais e nacionais de esportes náuticos e concursos de pesca.

Para a implantação das atividades turísticas na região norte do Lago de Furnas o território foi divido em quatro áreas, com o objetivo de reduzir os custos de manutenção e ampliar a atratividade dos empreendimentos turísticos.

A Área 01, que compreendia a margem direita do Lago de Furnas desde a barragem até a cidade de Capitólio, foi considerada como área prioritária para desenvolvimento. Os cânions, quedas d'água, as águas cristalinas do Lago de Furnas existentes naquela região foram apontados como elementos turísticos estratégicos. Propunha-se a implantação de parques, equipamentos recreativos, um complexo turístico privado de alto padrão e casas de veraneio e para finais de semana.

Para a Área 02, que ficava em Santo Hilário, distrito do município de Pimenta, recomendavase a implantação de equipamentos turísticos, comerciais e casas de veraneio. Sugeria-se o reflorestamento da montanha e a implantação de trilhas para passeio a pé e a cavalo e 
mirantes nos pontos mais altos voltados para as amplas vistas do Lago de Furnas. Os investimentos em Santo Hilário deveriam iniciar-se cinco anos após a implantação das melhorias na Área 01.

Na Área 03, situada em Carmo do Rio Claro, no braço do lago correspondente ao Rio Sapucaí, recomendava-se também a implantação de um complexo turístico privado, vinte anos após a implantação das obras previstas para a Área 01. Recomendava-se que a pequena capela situada no alto da Serra Tormenta a mais de 1200 metros de altura se transformasse num mirante turístico.

Para a Área 04, situada a margem esquerda do lago da ponte de Santo Hilário até a barragem de Furnas, previa-se a melhoria dos acessos rodoviários e por balsas e a implantação de equipamentos recreativos. Os investimentos para Área 04 deveriam ser implantados depois de 20 anos do início das obras na Área 01.

Propunha-se a melhoria do sistema viário com investimentos em rodovias, ferrovias e linhas aéreas. Entretanto, existiam poucas referências ao transporte aquático por barcos e balsas que haviam se transformado em um dos principais meios de transporte para interligação dos municípios atingidos pelo Lago de Furnas.

O plano previa a implantação de um sistema de parques composto por nove projetos situados no entorno do Lago de Furnas, que além de promover o lazer e o turismo atuariam como importantes instrumentos de preservação dos recursos ambientais regionais.

O equilíbrio entre os projetos de desenvolvimento e a preservação dos recursos ambientais do território deveria ser promovido por um Centro de Treinamento e Pesquisa de Recursos e Meio Ambiente que deveria ser implantado no entorno do Lago de Furnas.

Para acompanhamento do processo de implantação do PDLF seria proposta a criação da Agência de Desenvolvimento do Lago de Furnas que deveria ainda, controlar o desenvolvimento regional e implantar e operar os sistemas de recreação.

A implantação destes projetos deveria provocar um alto fluxo de pessoas para a região e as questões sanitárias deveriam ser objeto de ações específicas. O PDLF sugeria que o abastecimento de água poderia ser provido pelo próprio Lago de Furnas depois de tratamentos específicos em conjunto com outras fontes alternativas. Criticava-se a adoção 
de tanques sépticos para os esgotos domésticos, uma vez que os possíveis resíduos seriam direcionados diretamente ao Lago de Furnas. Recomendava-se a implantação de infraestruturas para o tratamento do esgoto que seria produzido na região.

A maioria das propostas e diretrizes do Plano de Desenvolvimento do Lago de Furnas não foram executadas.

\subsection{Os Planos Diretores Participativos dos municípios do entorno do Lago de Furnas}

A diretriz da criação da Agência de Desenvolvimento do Lago de Furnas pelo Plano de Desenvolvimento do Lago de Furnas parece ter sido plenamente atendida pela criação da Associação dos Municípios do Lago de Furnas (ALAGO) que foi instituída em 1994 com o objetivo estatutário de promover e induzir o desenvolvimento integrado dos municípios, nas áreas de saneamento básico, meio ambiente, transportes e turismo em toda a região do Lago de Furnas. Caberia ainda a ALAGO: o desenvolvimento da indústria, do comércio; da agricultura regional; permanente saneamento do lago; preservação dos mananciais e o saneamento básico dos municípios do Lago de Furnas (ALAGO, 2008).

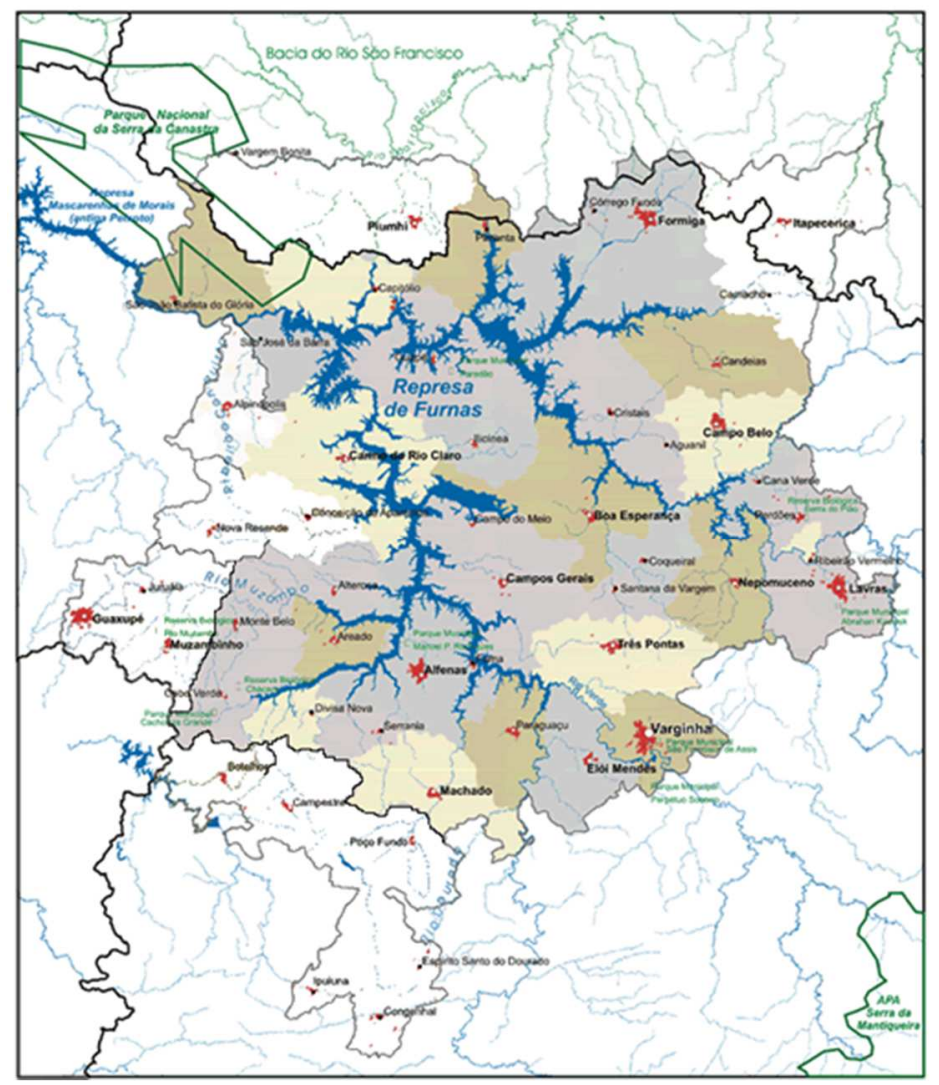

Figura 4 - Mapa dos municípios integrantes da ALAGO. 
Fonte: ASSOCIAÇÃO DOS MUNICÍPIOS DO LAGO DE FURNAS, 2008.

A ALAGO, desde a sua criação tem se configurado como a principal entidade representativa, do conjunto dos municípios da região, que livremente optaram por associar-se a esta instituição. Desde então, a ALAGO tem desenvolvido um conjunto de programas e projetos voltados principalmente ao turismo, a pesca, a piscicultura, recomposição da mata ciliar no entorno do lago e ao saneamento ambiental dos municípios. A ALAGO assumiu ainda funções políticas estratégicas, representando os interesses dos municípios junto ao Governo Estadual e Federal, bem como junto a empresa FURNAS Centrais Elétricas Ltda (FURNAS). Os municípios da região atingidos pelo Lago de Furnas recebem royalties, que são pagos por FURNAS devido aos danos ambientais e socioeconômicos causados na região pela produção de energia elétrica. A ALAGO atua, muitas vezes, como interlocutora destes municípios nas suas demandas junto a FURNAS referentes ao pagamento destes referidos royalties, que representam uma importante fonte de renda para gestão administrativa destes municípios (ALAGO, 2012; LEMOS JÚNIOR, 2010).

Uma das experiências mais importantes de planejamento integrado do território desenvolvida pela ALAGO, foi a coordenação do processo de elaboração de 50 Planos Diretores Participativos para os municípios situados no entorno do Lago de Furnas no período de 2006 a 2007.

Para elaboração dos Planos Diretores Participativos dos municípios do entorno do Lago de Furnas, o território foi dividido em nove microrregiões com o objetivo de que futuramente fossem desenvolvidos planos microrregionais que mais tarde integrariam um Plano Regional de Desenvolvimento da área de influência de Furnas (PEREIRA et al., 2006). É importante destacar que o referido Plano Regional de Desenvolvimento, não fazia parte das obrigações legais do Plano Diretor, previstas no texto lei do Estatuto da Cidade, configurando-se como uma iniciativa de planejamento regional definida pela ALAGO em conjunto com os representantes técnicos dos municípios envolvidos neste processo. 
Elaboração de 50

Planos Diretores dos

municípios do

entorno do Lago de

Furnas
Elaboração futura de

um Plano Regional

Divisão do território

em 09 Microrregiões

Elaboração de Planos

Microrregionais de Desenvolvimento

da área de influência

do Lago de Furnas

Figura 5 - Etapas do processo de planejamento local e regional proposto para o território do entorno do Lago de Furnas

Fonte: PEREIRA et al., 2006.

As nove microrregiões foram constituídas por lotes de quatro ou seis municípios definidas segundo critérios que observaram a proximidade geográfica e a população total (FERREIRA; CARDOSO, 2008).

Posteriormente apenas 29 municípios aprovaram seus Planos Diretores Participativos nas Câmaras Municipais transformando-os em leis municipais. Em 23 municípios, os Planos Diretores apresentaram diretrizes específicas de desenvolvimento regional que extrapolavam os limites administrativos dos territórios municipais e encaminhavam propostas e projetos para o desenvolvimento sustentável da região. Como o Plano Diretor Participativo é uma lei municipal, estas diretrizes de desenvolvimento regional devem ser entendidas como procedimentos obrigatórios, e devem necessariamente serem observados pelos gestores municipais.

Após a conclusão dos Planos Diretores, em 2007, e o consequente cumprimento dos prazos legais os municípios se desmobilizaram e a esperada elaboração dos Planos Microrregionais e do Plano Regional de Desenvolvimento da área de influência do Lago de Furnas não se efetivaram. 


\subsection{O Plano Diretor de Recursos Hídricos da Bacia do Entorno do Reservatório de Furnas (PDRH FURNAS)}

Mais tarde, em 2008, a ALAGO firmou um convênio com a Secretaria de Estado de Meio Ambiente e Desenvolvimento Sustentável de Minas Gerais (SEMAD) e o Instituto Mineiro de Gestão das Águas (IGAM) para o desenvolvimento do Plano Diretor de Recursos Hídricos da Bacia do Entorno do Reservatório de Furnas (PDRH FURNAS). Cabe ressaltar que como previu a Lei no 9433/97, o IGAM, a Agência de Águas de Minas Gerais era entidade responsável pelo processo de elaboração do PDRH FURNAS.

A Fundação de Pesquisa e Assessoramento à Indústria (FUPAI), instituição vinculada à Universidade Federal de Itajubá (UNIFEI) foi contratada para a elaboração do PDRH FURNAS. As atividades foram acompanhadas por grupos técnicos indicados pelo IGAM e pelo Comitê da Bacia Hidrográfica do entorno do Lago de Furnas (CBH FURNAS) (ALAGO, 2013b).

O PDRH FURNAS desenvolveu uma ampla análise regional da Unidade de Planejamento e Gestão dos Recursos Hídricos Grande 3 Furnas (UPGRH-GD3 FURNAS) que abrange o território total ou parcial de 48 municípios do entorno no Lago de Furnas. A grande maioria desses municípios, ou seja $80 \%$ deles, eram municípios com menos de 20.000 habitantes (ALAGO, 2013a).

Na época a região da UPGRH GD3 FURNAS vivia um processo de esvaziamento do espaço rural e um consequente aumento da população em áreas urbanas. O fenômeno era explicado pela falta de oportunidades de emprego principalmente para os jovens e a limitada oferta de serviços básicos (ALAGO, 2013a).

O PDRH FURNAS identificou então os principais problemas ambientais do território: deficiência nos tratamentos de esgotos sendo que 70\% dos municípios não possuíam sistemas de tratamento de esgotos sanitários encaminhando seus efluentes para os rios municipais que na maioria das vezes desaguavam no Lago de Furnas; disposição inadequada de resíduos sólidos sendo que apenas dois municípios possuíam aterros sanitários; aumento progressivo do uso das águas para irrigação e para o abastecimento público; baixa cobertura vegetal nas áreas de proteção permanente e a poluição das águas por agrotóxicos e fertilizantes agrícolas.

A baixa qualidade das águas era apontada como o maior desafio a ser enfrentado. O PDRH FURNAS indicava então a necessidade da construção de um pacto com os usuários da UPGRH GD3 FURNAS, entre os quais, os municípios para a melhoria da qualidade dos 
recursos hídricos daquele território. Várias diretrizes foram encaminhadas para o enfrentamento desse objetivo.

O PDRH FURNAS, ao contrário dos 50 Planos Diretores Participativos, possibilitou uma visão abrangente do território integrando os $16.507 \mathrm{~km}^{2}$ da Unidade de Planejamento e Gestão de Recursos Hídricos Grande 3 do Entorno do Lago de Furnas em projetos e diretrizes voltadas à preservação dos recursos hídricos regionais. As fronteiras administrativas dos municípios foram extrapoladas para a construção de um pacto regional para a melhoria da qualidade dos recursos hídricos daquele território.

A experiência do enfrentamento coletivo dos problemas regionais promovida pela ALAGO em conjunto com os municípios do entorno do Lago de Furnas construiu uma identidade regional e uma visão integrada e cooperativa do seu território manifestada no conteúdo da maioria de seus Planos Diretores, concluídos em 2007, quanto no PDRH FURNAS, concluído em 2013.

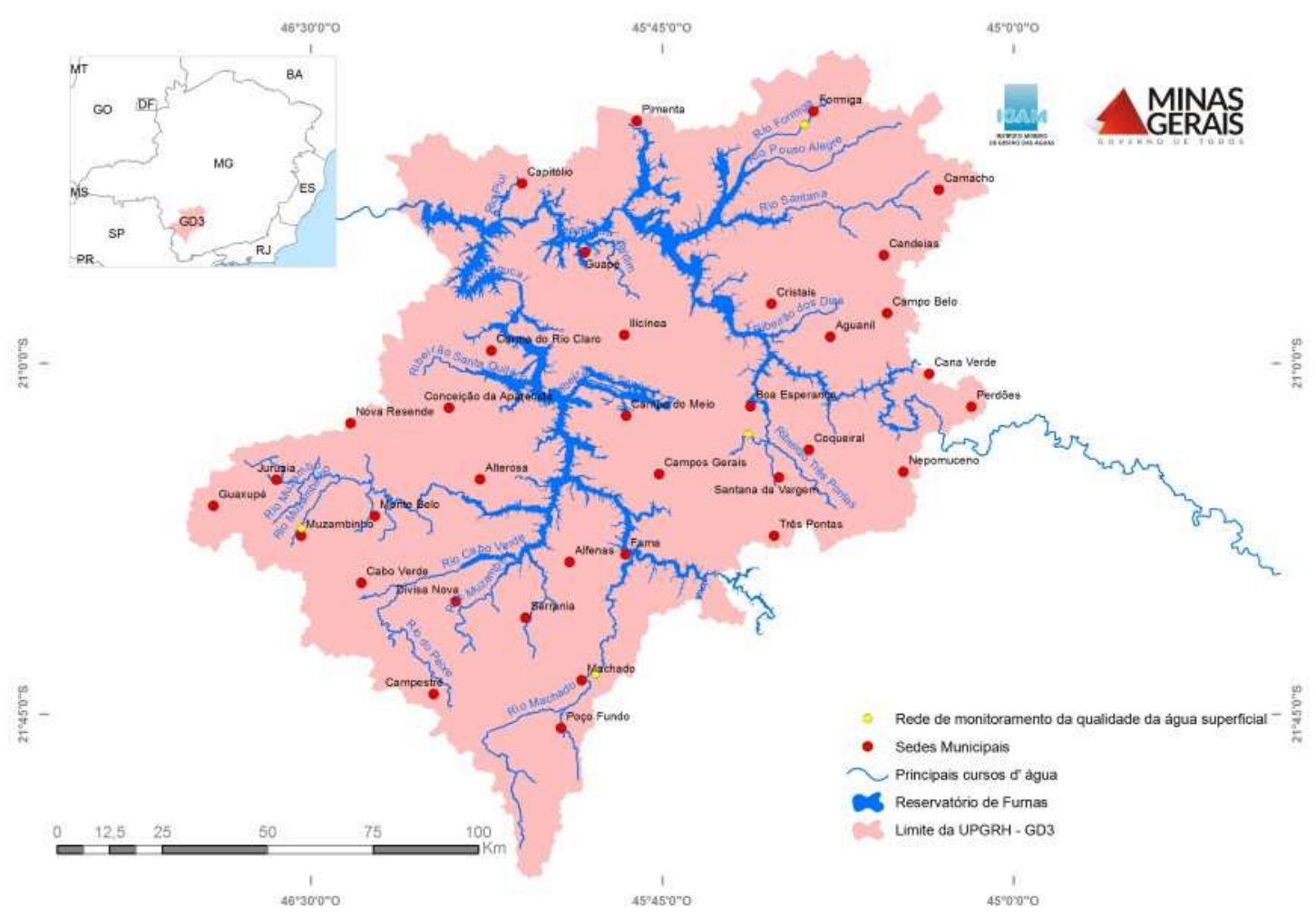

Figura 6 - Mapa da UPGRH GD3 FURNAS.

Fonte: IGAM, 2016. 


\section{Conclusão}

O Ordenamento do Território brasileiro ainda se configura como um desafio a ser enfrentado para a definição e concretização de estratégias de desenvolvimento que contemplem o conjunto do território nacional. A interrupção do debate sobre a PNOT evidencia a lacuna do papel do Estado que deveria de acordo com o texto constitucional ser o principal protagonista desse processo.

O entendimento, previsto na PNOT, do conceito do Ordenamento Territorial como um processo voltado à definição dos usos possíveis do território para a promoção do desenvolvimento econômico, da qualidade de vida e da preservação do meio ambiente carece de meios e estratégias para sua viabilização no contexto brasileiro.

O principal instrumento de planejamento do uso do solo nacional, ou seja, o Plano Diretor, previsto na Constituição Federal de 1988 e no Estatuto da Cidade de 2001, não tem obrigação legal de abordar o território regional. Suas propostas devem necessariamente voltar-se para os limites do município compreendendo tanto a sua área urbana como a rural.

Por outro lado, o Plano de Recursos Hídricos, previsto na Política Nacional de Recursos Hídricos de 1997, apesar de abordar o território regional, ou seja, o território da Bacia Hidrográfica incluindo um conjunto de municípios concentra suas diretrizes no planejamento e preservação das águas. O Plano de Recursos Hídricos, apoiado nas discussões e debates que acontecem nas agências e comitês de Bacias Hidrográficas, se configura como o único instrumento de planejamento oficial que contempla o território regional para implementação de políticas de planejamento e preservação das suas águas.

Umas das grandes contribuições dos Planos de Recursos Hídricos no campo do planejamento e gestão territorial brasileira residem no fato do mesmo possibilitar o desenvolvimento de acordos e pactos que superam os limites administrativos e legais dos estados e municípios enfocando em suas propostas, ações e programas o território da bacia hidrográfica, mas a sua abordagem está confinada ao tema das águas.

Faltam no contexto brasileiro, instrumentos de planejamento e gestão abrangentes que superem os limites legais dos estados e municípios voltados à busca de um desenvolvimento 
territorial integrado que abordem o desenvolvimento econômico, a preservação do meio ambiente e a melhoria da qualidade de vida das populações envolvidas. Há de se considerar que os planos de desenvolvimento regional poderiam suprir esta lacuna promovendo processos e estratégias para o desenvolvimento sustentável do território regional.

Com a falta de uma política governamental, as ações de ordenamento territorial podem ser assumidas por um conjunto de municípios integrados em programas e projetos comuns e cooperativos. Nesse contexto, as experiências de planejamento dos municípios do entorno do Lago de Furnas indicam alternativas para a ordenação do território regional. Estes municípios aprenderam a se reunir em torno de uma associação e discutir de maneira integrada os problemas do seu território, mas mostraram incapacidade para concretizar os Planos Microrregionais e o Plano Regional de Desenvolvimento.

Em síntese: o Plano de Desenvolvimento do Lago de Furnas de 1975 estabeleceu uma proposta de organização do território do entorno do Lago de Furnas considerando que as atividades turísticas seriam a principal estratégia de desenvolvimento para região. Apesar dessa premissa não ter se efetivado, a atuação conjunta dos municípios junto à ALAGO constituíram processos de integração regional que se consolidaram na campanha de elaboração dos Planos Diretores em 2006. As reflexões desenvolvidas nos processos de elaboração dos Planos Diretores levaram os municípios a entenderem que estavam poluindo os rios municipais com suas redes de esgoto e que estes mesmos rios desaguavam no Lago de Furnas poluindo o principal recurso hídrico regional que foi consolidado naquela região.

O Plano de Recursos Hídricos da UPGRH GD3 FURNAS se apresenta como um dos resultados deste processo indicando a necessidade da construção de um acordo regional para a melhoria da qualidade das águas daquela bacia hidrográfica.

Infelizmente os Planos Microrregionais e o Plano Regional de Desenvolvimento propostos na campanha dos Planos Diretores de 2006 não se efetivaram. O cumprimento das exigências legais de elaboração dos Planos Diretores Participativos e mais tarde do PDRH FURNAS desmobilizaram os municípios da região. Entretanto, o conhecimento e a experiência acumulada nesses processos podem permitir que estes mesmos municípios desenvolvam estes planos futuramente. 
O caráter holístico do Ordenamento Territorial, além de enfrentar o tema das desigualdades socioeconômicas regionais, aborda ainda as qualidades, as potencialidades e os problemas da região e de sua população objetivando a construção coletiva de um projeto de futuro para esse mesmo território.

Nesse contexto, o papel do Estado seria muito importante, mas não fundamental. A responsabilidade pelo Ordenamento Territorial poderia ser assumida pelos principais interessados, ou seja, a comunidade regional.

A experiência acumulada de enfrentamento dos problemas regionais desenvolvidas pelos municípios do entorno do Lago de Furnas apresenta uma alternativa estratégica para os pequenos e médios municípios brasileiros. Nesse sentido, independentemente de uma política estruturada do Governo Federal para o território os próprios municípios poderiam se organizar e conceber coletivamente um projeto cooperativo e integrado de Ordenamento Territorial.

Neste contexto, a Bacia Hidrográfica, prevista na Lei Federal n 9433/1997 como unidade territorial para implementação da Política Nacional de Recursos Hídricos se apresenta como um espaço estratégico para adoção de programas de ordenamento territorial. Na Bacia Hidrográfica há um conjunto de municípios que estão integrados pelo mesmo sistema hídrico, conformando um território com uma profunda complexidade socioambiental. Assim não bastam ações singulares voltadas exclusivamente às águas ou às cidades, ao contrário, programas integrados e cooperativos voltados à promoção do desenvolvimento econômico, da qualidade de vida e da preservação do meio ambiente podem de se apresentar como referências para os programas de ordenamento territorial brasileiros. Um caminho semelhante tem sido adotado pelos municípios do entorno do Lago de Furnas.

\section{Referências bibliográficas}

ALAGO. Associação dos Municípios do Lago de Furnas (Org.). (2008) Estatuto Social da ALAGO. Alfenas. Disponível em: http://www.alago.org.br/imagens/file/estatuto.pdf. [Consultado em 28 de janeiro de 2017].

ALAGO. (2012) ALAGO trabalhando pela região do Lago de Furnas. Revista da ALAGO. Alfenas, v.1, n. 1, p. 4-5, mar. 2012. 
ALAGO. (2013a) PDRH FURNAS - Plano Diretor de Recursos Hídricos da Bacia Hidrográfica do Entorno do Lago de Furnas: Relatório Parcial 1: Diagnóstico da Bacia Hidrográfica. Alfenas: ALAGO. Disponível em: http://portalinfohidro.igam.mg.gov.br/planos-diretores/bacia-hidrografica-do-rio-grande/upgrhgd3entornodo-reservatorio-de-furnas/8261-. [Consultado em 13 de novembro de 2016].

ALAGO. (2013b) PDRH FURNAS - Plano Diretor de Recursos Hídricos da Bacia Hidrográfica do Entorno do Lago de Furnas: Relatório Parcial 1: Resumo Executivo. Alfenas: ALAGO. Disponível em: <http://portalinfohidro.igam.mg.gov.br/planos-diretores/bacia-hidrografica-do-rio-grande/upgrhgd3entornodo-reservatorio-de-furnas/8265-pdrhfurnasresumo-executivo2013>. [Consultado em 17 de maio de 2017].

BRASIL. Constituição (1988). Constituição da República Federativa do Brasil de 1988. Brasília, DF, 05 out. 1988. Disponível em: http://www.planalto.gov.br/ccivil_03/constituicao/constituicao.htm. [Consultado em 21 de agosto de 2017].

BRASIL (1997). Lei no 9433, de 08 de janeiro de 1997. Brasília, DF, 09 jan. 1997. Disponível em: http://www.planalto.gov.br/CCIVIL_03/leis/L9433.htm. [Consultado em 25 de agosto de 2017].

BRASIL (2001). Lei no 10257, de 10 de julho de 2001. Regulamenta os artigos 182 e 183 da Constituição Federal, estabelece diretrizes gerais da política urbana e dá outras providências. Lei no 10.257, de 10 de Julho de 2001: Estatuto da Cidade. Disponível em: http://www.planalto.gov.br/ccivil_03/leis/leis_2001/l10257.htm. [Consultado em 21 de agosto de 2017].

BRASIL (2003). Lei $n^{\circ} 10.683$, de 28 de maio de 2003. Dispõe sobre a organização da Presidência da República e dos Ministérios, e dá outras providências. Disponível em: http://www.planalto.gov.br/ccivil_03/leis/2003/L10.683.htm. [Consultado em: 05 de novembro de 2016].

BRASIL. Secretaria Estadual de Programas Urbanos. Ministério das Cidades. Plano Diretor Participativo. Brasília: Ministério das Cidades, 2005.

BRASIL (2007). Decreto no 6.047, de 22 de fevereiro 2007. Institui a Política Nacional de Desenvolvimento Regional - PNDR e dá outras providências. Disponível em: http://www.planalto.gov.br/ccivil_03/_ato20072010/2007/decreto/D6047.htm. [Consultado em 25 de agosto de 2017].

BRASIL (2007). Decreto de 12 de fevereiro de 2007. Institui o Grupo de Trabalho Interministerial - GTI para elaborar proposta da Política Nacional de Ordenamento Territorial - PNOT. Decreto de 12 de fevereiro de 2007. 1. ed. Disponível em: http://www.planalto.gov.br/ccivil_03/_Ato2007-2010/2007/Dnn/Dnn11196.htm. [Consultado em 24 de agosto de 2017].

BRASIL(2012). Lei no 12608, de 10 de abril de 2012. Institui a Política Nacional de Proteção e Defesa Civil PNPDEC; dispõe sobre o Sistema Nacional de Proteção e Defesa Civil - SINPDEC e o Conselho Nacional de Proteção e Defesa Civil - CONPDEC; autoriza a criação de sistema de informações e monitoramento de desastres; altera as Leis $n^{\text {os }} 12.340$, de 1o de dezembro de 2010, 10.257, de 10 de julho de 2014. Disponível em: http://www.planalto.gov.br/ccivil_03/_ato2011-2014/2012/lei/I12608.htm.[Consultado em 07 de setembro de 2017].

BRASIL, Ministério das Cidades. Plano Diretor Participativo: guia para a elaboração pelos municípios $e$ cidadãos. Tema 12: Plano Diretor e o Desenvolvimento Regional. Brasília: Ministério das Cidades, 2004.

BRASIL (2017). Decreto Lei no 782, de 31 de maio de 2017. Estabelece a organização básica dos órgãos da Presidência da República e dos Ministérios. Disponível em: http://www.planalto.gov.br/ccivil_03/_ato20152018/2017/Mpv/mpv782.htm. [Consultado em 24 de agosto de 2017].

BRASIL. PRESIDÊNCIA DA REPÚBLICA (1958). Programa de Metas do Presidente Juscelino Kubitschek: Estado do Plano de Desenvolvimento Econômico em 30 de junho de 1958. Rio de Janeiro.

BOLAFFI, Gabriel. Habitação e urbanismo: o problema e o falso problema. In: MARICATO, E. (org.) A produção capitalista da casa (e da cidade) no Brasil industrial. São Paulo: Alfa-Omega, 1982.

BUSCH, Amarílis; AMORIM, Sônia. A tragédia da região serrana do Rio de Janeiro em 2011: Procurando respostas. Distrito Federal: $2011 . \quad$ Disponível em: <http://casoteca.enap.gov.br/index.php?option=com_multicategories\&view=article\&id=50:a-tragedia-daregiao-serrana>. [Consultado em 07 de abril de 2018]. 
CONSELHO DA EUROPA. (1988). Carta Europeia do Ordenamento do Território. 1988. Disponível em: https://alojamientos.uva.es/guia_docente/uploads/2013/474/46059/1/Documento37.pdf. [Consultado em 22 de agosto de 2017].

CONTRIM, John R. (1994) A História de Furnas: Das Origens à Fundação da Empresa. Rio de Janeiro: Comitê Brasileiro do Conselho Mundial da Energia.

FERRÃO, João (2010) Ordenamento do território: 25 anos de aprendizagem. Europa Novas Fronteiras, Janeiro/Dezembro 2010, no 26/27, p. 77-84. Disponível em: http://hdl.handle.net/10451/11237. [Consultado em 24 de agosto de 2017].

FERREIRA, Mauro. Planejamento urbano nos tempos do SERFHAU: o processo de construção e implementação do plano diretor de desenvolvimento integrado de Franca. 2007. 1 f. Tese (Doutorado) - Curso de Doutorado em Teoria e História da Arquitetura e do Urbanismo, Universidade de São Paulo, São Paulo, 2007. Disponível em: <http://www.teses.usp.br/teses/disponiveis/18/18142/tde-20112007-105824/pt-br.php. [Consultado em 11 de abril de 2018].

FERREIRA, Mauro; CARDOSO, Emiliana Maquiaveli. (2008) Experiência de apoio técnico à construção dos Planos Diretores Participativos de cinco municípios de Minas Gerais pela FESP|UEMG. Ciência Et Praxis, Passos, v. 1, n. 1, p.39-46, mar. 2008. Disponível em: http://www.edifesp.fespmg.edu.br/index.php/scientae/article/view/7/8. [Consultado em 20 de julho de 2017].

GARSON, Sol. (2010) Metrópoles do Brasil. Rio de Janeiro: Observatório das Metrópoles, 2010. 8 p. Disponível em: http://www.observatoriodasmetropoles.net/download/observatorio_RMs2010.pdf. [Consultado em: 28 julho 2017].

HALL, Peter. (2005) Cidades do amanhã: Uma história intelectual do planejamento e do projeto urbanos no século XX. São Paulo: Perspectiva.

KRINGS, Ana Luiza Silva Spínola; ROSSIN, Antônio Carlos; PHILIPPI JUNIOR, Arlindo. (2006) Análise crítica do conceito de função social da propriedade urbana mediante estudo de caso na bacia hidrográfica do Guarapiranga - SP. Pós. Rev. Programa Pós-grad. Arquit. Urban. FAUUSP, [s.I.], n. 20, p.76-91, 1 dez. Universidade de São Paulo Sistema Integrado de Bibliotecas - SIBIUSP. DOI: 10.11606/ISSN.2317-2762.v0i20, p.76-91. Disponível em: http://www.revistas.usp.br/posfau/article/view/43486. [Consultado em: 24 de agosto de 2017].

LEMOS JÚNIOR, Clésio Barbosa (2010). A Implantação da Usina Hidrelétrica de Furnas e suas Repercussões: Estudo sobre a Territorialização de Políticas Públicas. 116 f. Dissertação (Mestrado) - Curso de Geografia, UNICAMP,Campinas,2010.Disponível em: http://www.bibliotecadigital.unicamp/document/?code=000778319. [Consultado em: 26 de dezembro de 2016].

MATOS, Ralfo. (2000) Aglomerações Urbanas, Redes de Cidades e Desconcentração Demográfica no Brasil. In: Anais Encontro Nacional de Estudos Populacionais, 12, Caxambu. Anais Encontro Nacional de Estudos Populacionais. Belo Horizonte: ABEP, 2000. p. 200 - 210. Disponível em: <http://www.abep.nepo.unicamp.br/docs/anais/pdf/2000/todos/migt4_3.pdf>. [Consultado em: 27 de julho de 2016].

MIRAGAYA, Júlio; SIGNORI, Leandro. (2011) A Importância da Política de Ordenamento Territorial (PNOT) para o Desenvolvimento Sustentável Brasileiro. In: FARIA, Rodrigo de; SCHVARSBERG, Benny. Políticas Urbanas e Regionais no Brasil. Brasília: Universidade de Brasília - Faculdade de Arquitetura e Urbanismo,. Cap. 6. p. 137167. Disponível em: https://www.academia.edu/3837583/Politicas_Urbanas_Regionais_2011. [Consultado em: 24 de agosto de 2017].

MINAS GERAIS. A. J. Gray. Governo do Estado de Minas Gerais. Plano de Desenvolvimento do Lago de Furnas. Belo Horizonte: Secretaria da Indústria, Comércio e Turismo do Estado de Minas Gerais, 1975.

MINAS GERAIS. IGAM. GD3 - CBH do Entorno do Reservatório de Furnas. Portal dos Comitês. Disponível em: http://comites.igam.mg.gov.br/comites-estaduais-mg/gd3-cbh-entorno-do-reservatorio-de-furnas.

[Consultado em: 25 de agosto de 2017].

MOTA, Juliana Costa. Uma análise da criação e da atuação do SERFHAU. In: XII ENCONTRO DA ASSOCIAÇÃO NACIONAL DE PÓS-GRADUAÇÃO E PESQUISA EM PLANEJAMENTO URBANO E REGIONAL, 12., 2007, Belém. Anais do XII ENA. Belém: XII Encontro da Associação Nacional de Pós-graduação e Pesquisa em Planejamento 
Urbano e Regional, 2007, Belém: AMPUR, 2007. v. 1, p. 02 - 20. Disponível em: http://www.ufpa.br/xiienanpur/CD/ARQUIVOS/GT4-377-417-20061229202148.pdf. [Consultado em: 08 de agosto de 2014].

PEREIRA, Cadmila Arislene et al. (2005) Metodologia para Elaboração/Revisão de Planos Diretores Participativos. In: IV Congresso Brasileiro de Direito Urbanístico, 2006, São Paulo: Ibdu, , v.1, p.13-33. Disponível em: http://www.ibdu.org.br/imagens/METODOLOGIAPARAELABORAcaOREVISaO.pdf. [Consultado em: 10 de maio de 2017].

SANTOS, Thereza Carvalho Santos. Ministério de Integração Nacional. Algumas considerações preliminares sobre Ordenamento Territorial: PARA PENSAR UMA POLÍTICA NACIONAL DE INTEGRAÇÃO REGIONAL. Brasília, 2005. 78 p. Disponível em: http://www.mi.gov.br/c/document_library/get_file?uuid=3fc31d16-e5f7-46fbb8cc-0fb2ae176171\&groupld=24915. [Consultado em: 25 de agosto de 2017].

TUCCI, Carlos E. M.; MENDES, Carlos André. Avaliação Ambiental Integrada de Bacia Hidrográfica. Brasília: MMA, 2006. Disponível em: <http://www.mma.gov.br/estruturas/sqa_pnla/_arquivos/sqa_3.pdf>. [Consultado em: 26 de março de 2016].

TUNDISI, José Galizia. Água no Século XXI: Enfrentando a Escassez. São Carlos, Rima, 2009. 